\title{
Suluk Gus Dur Reconstruction of Local Culture in the Context of Sufism
}

\author{
M. Agus Kurniawan; Munir; Cholidi \\ Doctoral Program in Islamic Civilization, Raden Fatah State Islamic University Palembang, Indonesia
}

http://dx.doi.org/10.18415/ijmmu.v8i9.3029

\begin{abstract}
"Community systems are created, maintained, or modified by human behavior and interaction," say Berger and Luckman. Society and social institutions are objectively realistic, but in reality they are all subsumed into subjective definitions through a process of interaction. New objectivity emerges through repeated affirmations given by other people who have the same subjective definition of that definition. At the highest geological level, humans created the world in a universal, universal and symbolic sense. In short, in a holistic view of life, Suluk Gus Dur's teachings of Sufism are Islamic teachings that focus on awareness whole self. Awareness and self-centered understanding of Islam as a whole. Awareness of having a noble personality,and personality creates a personality based on self-awareness that emerges from social attitudes and becomes a highly socially conscious social personality.
\end{abstract}

Keywords: Suluk Gusdur; Local Cultural Construction; Sufism

\section{Introduction}

One of the syiiran that contains religious values is Gus Dur's suluk. Suluk which will be the study of this author is Syiir as a result of acculturation of Islamic teachings with the study of Javanese culture created by KH Muh. Nizam As-Shofa, caregiver of the Ahlus-shofa Islamic Boarding School, Wal Wafa Simoketawang, Wonoayu, Sidoarjo, East Java. Many people think that Gus Dur's suluk by the community, especially Nahdhiyin residents, is the work of (late) Gus Dur from the side of the singer's voice to the content of Syiiran that is very identical to the figure of Gus Dur when in fact the syiir has existed long before that, precisely since 2004 ago. ${ }^{1}$ Gus Dur's suluk which consists of small suluk (khalwat fi al-khalwat) and large suluk (khalwat fi al-jalwat) is a form/variant of suluk itself. While Suluk Nafs / purification of the soul and Suluk Qalb / purification of the heart is called (Takhalli / purgative) then the emptying of sirr (Tahalli / contemplative) then enlightenment of the spirit (Tajalli / illuminative) is a process or stage that must be passed in the form of this suluk where small and The big suluk was in the Qalb suluk (Takhalli / purgative) and the emptying sirr (Tahalli / contemplative).

The development of poetry in society varies. Like the Suluk Gus Dur created by Gus Nizam in 2004. Suluk Gus Dur uses simple language, but the language contains symbols with a meaning. In order to understand the meaning of Gus Dur's suluk, it will be studied using the theory of Peter L. Berger \& Thomas

${ }^{1}$ Erfandi Putra, Syiir Without Waton and Its History, As-Shofa, 25 December 2015-2 March 2019, p. 17. 
Luckman which is based on social construction. ${ }^{2}$ According to Braginsky "As previously mentioned, Gus Dur's suluk basically uses simple Javanese language that is easily understood by Javanese people in general. However, cultural knowledge will reveal more about the teachings contained in the syiir so that they can be applied to everyday life."3Unified Sufism on aesthetic tools, specifically literary tools, has provided evidence that Sufism teachings are often preached with literary aesthetic tools. This was later called by Braginsky "with the term poetic Sufism, while Sufism written in the form of spiritual doctrine is referred to as Book Sufism."

Suluk Gus Dur according toAhmad Shofi Muhyiddin is "a distinctive feature of poetic Sufism with Javanese language and often uses absorptions from Arabic and Kawi which contain an invitation to understand Islam comprehensively from the Sufism approach with four stages of maqamat namely: sharia, tarekat, essence, and makrifat."4

Awareness of the value of life that comes from humans is apparently unable to overcome the negative effects of modernization because the source of divine revelation is the source of holding the value of essential life. One of the efforts made to explore the value of life that comes from divine revelation is to undergo suluk play.

\section{Gus Dur's Suluk Writing History}

In a cultural context, Suluk Gusdur is here to watermoral aridity of today's society. Urgent center of gravityso that this poem can be present in the midst of a disease that plagues societyend-time society is a conscious form of concern forthe many tragedies of deviations from the purity of religious teachings. The purity of religious teachings is increasingly difficult to obtain.

Unfaithful cultureincreasingly flooding the common people who are still in the learning process study Islam. The impact of the tight understanding of religion is finally getting worseaway from the status of Islam as a religion that is rahmatan lil 'alamin.Moving away from the status of Islam as a religion of rahmatan lil 'alamin, isn't it?because of external factors, precisely internal factors. Islam seems brokenbecause in the body of Islam itself.

For this awareness, Suluk Gusdur is present as a medicine forthe phenomenon. Guiding understanding of Islam is not only from the sideoutside or the Shari'a, but even more deeply, Muslims are invited tounderstand Islam more deeply, namely in the realm of Sufism. This poemtrying to make one's heart always wet with the Koran and hadith. Being a tolerant human being, understanding religion as seen fromside of altitude, so that you can see the benefits and harms of variousside. Far from the shallow understanding that resulted in a personbarren in understanding religion.

When Gus Nizam first played the sy'ir born fromthe process of seclusion and seclusion for ten days. It was the beginningGusdur's Suluk language used is not what it is today.Initially, the syi'ir consisted of 17 stanzas. On consideration,finally downsized to 13 stanzas as it is today. After the versewritten, he tried to find the right title. So he's inspiredwith a song titled "Untitled". Finally the man who once studied at Lirboyo, this also gave the name syi'iran which is he wrote under the name Syi'ir Tanpo Wathon, which inJava, whaton means limit. It means that Syi'ir Tanpo Wathon has the meaning of syi'ir without limits.

Broadly speaking, this syi'ir starts fromproblem and ends with a solution. All those problemsis a recording of the young Kiai on various problems thatentangle the lives of Muslims today. In addition, it is also aself-criticism of the existence of the role of ulama', religious teachers and Muslim students. ${ }^{5}$

\footnotetext{
${ }^{2}$ Peter L Berger and Thomas Luckman, Social Interpretation of Reality, (Jakarta: LP3S, 1990) p 41

${ }^{3}$ Braginsky, The Merciful Beauty and Kamal; History of Malay Literature in the 7th-9th Century, (Jakarta: INIS, 1998$)$, p. 14.

${ }^{4}$ Ahmad Shofi Muhyiddin, Syiir Without Waton Al-Maghfurlah KH Abdurrahman Wahid (Gus Dur), (Yogyakarta: 2015), p. 25

${ }^{5}$ Ibid., 34
} 


\section{Suluk Gus Dur Reconstruction of Islamic Boarding School Culture}

Etymologically, suluk means mystical, or the path to inner perfection. In addition to this understanding, in another perspective, suluk is defined as seclusion, self-isolation and the sciences of Sufism or mysticism. In Javanese literature, suluk means teaching, philosophy to seek the relationship and unity of man with God, while in the art of dalang, suluk can be interpreted as the song of the puppeteer to create a certain atmosphere. ${ }^{6}$

Broadly speaking, according to A. Rivay Siregar that "suluk is a person's activity to get closer to God, suluk is almost the same as tarekat, namely a way of getting closer to God. It's just that the tarekat is still conceptual in nature, while suluk is already in operational technical form." ${ }^{7}$

Suluk in terms of Sufism is a way to get closer to Allah SWT (marifat). Then the term is used for an activity by individuals in order to achieve ikhwal (mental state) or a state.

The key to interpreting Sufism, suluk means a spiritual process towards the Creator. This phenomenon is a method of traveling to various conditions and positions. The path taken by a person (salik the servant) who has gone far towards Allah is one who has truly shown his servitude to Allah. ${ }^{8}$

Suluk Gus Duris a suluk presented by KH Abdurahman Wahid (Gus Dur) containing an invitation to understand Islam thoroughly from the Sufism approach through 4 stages, namely sharia, tariqat, makrifat, and essence.Gus Dur's Suluk with the theme Syiir Tanpo Waton already relevant at the time of presentation in the current era. Suluk Gus Durnamely a wise invitation that gives a spirit of peace to readers and an invitation to Islamic studies.

Syir on Gus Dur's Suluk This song is called Syiir Tanpo Waton which means (Poetry Without Limits) is named like that because this syiir calls for always remembering Allah without stopping, being patient without limits, being grateful at all times, seeking knowledge until death. This poem is classified as a religious poem intended to reflect and remind again of the importance of life oriented to the Hereafter.

This is reflected in Gus Dur's Suluk, which places a lot of emphasis on the practice of Sufism, such as cleansing the mind and heart with dhikr, suluk and riyadhah. This was reinforced by Gus Dur's statement, the character of the Sufism movement gave very little priority to the expression of the beauty of abstract love for God, but only concerned with the work of worship which was considered the main thing. According toAbdurahman Wahid "Sufism in the archipelago emphasizes the formation of values that are practiced in everyday life and emphasizes the depth of taste factor."

The reconstruction of the local culture of the pesantren is a meaning made by each santri of the pesantren environment and aspects outside of him regarding the basics of Islamic teachings. The basics of Islamic teachings include aqidah, sharia, and morals to enter into the self-awareness of each individual in carrying out activities of daily life. Gus Dur's Suluk contains religious discourses and life motivations with each verse with philosophical meaning, including the depth of the meaning of Sufism and monotheism wrapped in the Javanese Kawi language. The purpose of making Gus Dur's suluk where the main target is "purification of the heart, then a steady heart arrangement to obtain a strong belief in right".

In a cultural context, Suluk Gus Dur is here to fix the moral deficiencies of today's society. The emphasis that urges this Suluk to be present in the midst of the social ills of the people of the end times is a form of awareness of the concern over the many tragedies of deviations from the purity of religious teachings. The purity of religious teachings is increasingly difficult to find. The culture of disbelief is increasingly flooding the common people who are still in the process of learning to explore Islam. The impact of the short understanding of religion is finally getting further away from the status of Islam as a religion that is rahmatan lil 'alamin.

${ }^{6}$ Kontjaraningrat, Javanese culture. (Jakarta: Balai Pustaka, 1984), p. 316

${ }^{7}$ A. Rivay Siregar, Sufism: From Kalsik Sufism to Neo-Sufism, (Jakarta: PT Raja Grafindo Persada, 2002), p. 281

${ }^{8}$ Amatullah Armstrong, The Key to Entering the World of Sufism: A Treasure of Sufi Terms, (Bandung: Mizan, 1996), p. 268

${ }^{9}$ Abdurahman Wahid, Flower Potpourri of Islamic Boarding Schools: A Collection of Abdurahman Wahid's Writings. (Jakarta: CV Dharma Bhakti, th) h. 29 
Based on these conditions, Suluk Gus Dur was present as a remedy for this phenomenon. The understanding of Islam that is led is not only from the outside or the Shari'a, but Islam is even deeper, namely Muslims are invited to understand more in the realm of Sufism. This Suluk tries to make one's heart always wet with the Qur'an and hadith. Being a tolerant person, understanding religion from a high point of view, so that you can see the benefits and harms from various directions.

With this awareness, Suluk Gus Dur is present as a remedy for this phenomenon, a silencer against the echoes of unrest in the body of Muslims. Leading the understanding of Islam is not only from the outside or the shari'ah. But deeper, Muslims are directed to understand Islam more deeply through the realm of Sufism. This Suluk seeks to make the heart always wet through dhikr, reading the Koran and hadith.

\section{Suluk Gusdur's Sufism Teachings}

According to Widodo"Suluk Gus Dur is a distinctive style of poetic Sufism with Javanese language and uses many absorptions from Arabic and Kawi languages. This was chosen as a strategy to broadcast the teachings of Sufism that were conceived by using a cultural strategy." 10 Meanwhile, according to Regards:"The teachings of Sufism in Gus Dur's Suluk are practical Sufism, not philosophy. The figure who carries philosophy-oriented Sufism is Ibn Arabi, while the figure who carries practical Sufism or Sunni Sufism is al-Ghazali." ${ }^{11}$ Practice Sufism is called individual mysticism and philosophical Sufism is called infinite mysticism. The practice of Sufism focuses on the individual's personality which is processed with a series of teachings through the practice of dhikr, tirakat and wirid. This was reinforced by Gus Dur's statement, the character of the Sufism movement gave very little priority to the expression of the beauty of abstract love for God, but only concerned with the work of worship which was considered the main thing. According toAbdurahman Wahid "Sufism in the archipelago emphasizes the formation of values that are practiced in everyday life and emphasizes the depth of taste factor." ${ }^{12}$

Suluk Gus Dur's teachings as a whole are Islamic teachings that focus on self-awareness. Appreciation and understanding of Islam as a whole centered on self-awareness will create a personality with noble character and good character. Budi character is based on self-awareness which becomes a social personality with high social awareness which shows from social attitudes. In Suluk Gus Dur explained and explained the understanding of the formation of self-awareness. Self-understanding is reflected in social attitudes which are reflected in the character and morals of a person who has completed all stages (salik).

In Gus Dur's Suluk, the order of shari'a, thareqat, marifat, and essence does not only look at rhyme singir, but a systematic sequence of stages of the science of Sufism. This is supported by the array because the ngilmune series is well established, because the stages of knowledge are solid, the word series means a coherent sequence, series I, series II, and so on with the content of stages in a systematic and sequential manner. Thus, the stage of Sufism in Gus Dur's Suluk begins with the Shari'a, thareqat, marifat, and essence. The sequence of these stages is different from the stages of Sufism in general, which prioritizes nature after that, then martyrdom, but the order of Gus Dur's Suluk pattern is marifat and essence.

The stage was originally from the 'outside' to the 'inside', through the road (salik) one should not be trapped in one station, let alone the outermost station, namely the Shari'a. In Suluk Gus Dur in verse IV forbids Muslims to stop only at the stage (maqam) of the Shari'a. The teachings of Sufism implicitly teach "supplies" to return to God. In closing, Gus Dur's Suluk ended with an affirmation when he died that he knew the way to face the Khaliq, the journey of the spirit did not get lost. In Javanese mysticism we find "the expressions die sakjeroning urip, urip sakjeroning die, die in life, live in death as a reflection of the essence of life and death in the footsteps and sighs that go hand in hand."

Humans who reach the essence of life as a whole means that they already know the real place of heaven. As a personal figure, he certainly exudes divine values from within the noble values.

\footnotetext{
${ }^{10}$ Widodo, Wahyu. Synonyms of Repetition of Meaning in Singiran Without Waton Gus Dur.(Yogyakarta: Graha Ilmu: 2011$)$. h 7

${ }^{11}$ Regards, Aprinus. Opposition of Sufi Literature. (Yogyakarta: Lkis 2004) h. 29

${ }^{12}$ Abdurahman Wahid, Flower Potpourri of Islamic Boarding Schools: A Collection of Abdurahman Wahid's Writings. (Jakarta: CV Dharma Bhakti, th) h. 29
} 


\section{Conclusion}

Reading these Gus Nizam's poems, the reader will quickly find his trademark. The hallmark of Gus Nizam's poetry in Gusdur's Suluk is in expressing its language "not beautifying the words", however, the "simplicity of the rhyme language" does not mean that the meaning of the poem becomes clear, because after all, the poem is so rich in symbols that are related to the realm of religious thought, even Islamic mysticism (Sufism). Love poetry in Sufism or Sufism becomes an important tool for the formation of noble character or morals.

\section{Reference}

Erfandi Putra, Syiir Without Waton and Its History, As-Shofa, 25 December 2015-2 March 2019.

Peter L Berger and Thomas Luckman, Social Interpretation of Reality, (Jakarta: LP3S, 1990).

Braginsky, The Merciful Beauty and Kamal; History of Malay Literature in the 7-9 Century, (Jakarta: INIS, 1998).

Ahmad Shofi Muhyiddin, Syiir Without Waton Al-Maghfurlah KH Abdurrahman Wahid (Gus Dur), (Yogyakarta: 2015).

Kontjaraningrat, Javanese culture. Jakarta: Balai Pustaka, 1984.

A. Rivay Siregar, Sufism: From Kalsik Sufism to Neo-Sufism, (Jakarta: PT Raja Grafindo Persada, 2002).

Amatullah Armstrong, The Key to Entering the World of Sufism: A Treasure of Sufi Terms, (Bandung: Mizan, 1996.

Abdurahman Wahid, Flower Potpourri of Islamic Boarding Schools: A Collection of Abdurahman Wahid's Writings. (Jakarta: CV Dharma Bhakti, thn).

Widodo, Wahyu. Synonyms of Repetition of Meaning in Singiran Without Waton Gus Dur. (Yogyakarta: Graha Ilmu: 2011).

Regards, Aprinus. Opposition of Sufi Literature. (Yogyakarta: Lkis 2004).

Abdurahman Wahid, Flower Potpourri of Islamic Boarding Schools: A Collection of Abdurahman Wahid's Writings. (Jakarta: CV Dharma Bhakti, thn).

\section{Copyrights}

Copyright for this article is retained by the author(s), with first publication rights granted to the journal.

This is an open-access article distributed under the terms and conditions of the Creative Commons Attribution license (http://creativecommons.org/licenses/by/4.0/). 